\title{
PERAN POLA ASUH ORANG TUA TERHADAP KEMATANGAN SOSIAL ANAK USIA PRASEKOLAH (PENDEKATAN TEORI BANNARD)
}

\author{
Innez Karunia Mustikarani, Martina Ekacahyaningtyas, Nur Rakhmawati \\ Prodi Sarjana Keperawatan dan Profesi Ners, Universitas Kusuma Husada Surakarta \\ innez.km@ukh.ac.id
}

\begin{abstract}
Abstrak
Pendahuluan: Pola asuh orang tua sangat penting peranannya dalam pengembangan psikologi anak karena bisa membentuk kepribadian anak di masa depan. Kematangan sosial merupakan suatu perkembangan ketrampilan dan kebiasaan-kebiasaan individu yang menjadi ciri khas kelompoknya. Beberapa anak di sekitar kita mungkin mengalami hambatan kematangan sosial misalnya anak belum mampu menyelesaikan tugas perkembangan pada usianya, seperti anak berusia 3 tahun yang belum mampu buang air kecil di toilet.

Tujuan: Penelitian ini bertujuan untuk mengetahui hubungan peran pola asuh orang tua terhadap kematangan sosial anak usia prasekolah.

Metode: Metode penelitian ini adalah observasional analitik dengan rancangan penelitian cross-sectional. Teknik pengambilan sampel dengan total sampling dimana jumlah sample penelitian adalah 30 responden. Instrumen Pola asuh orang tua menggunakan Parenteral Authority Questionnary (PAQ) dan kematangan sosial menggunakan Vineland Social Maturity Scale (VSMS). Analisis penelitian menggunakan uji Kendall Tau.

Hasil: Penelitian ini didapatkan hasil angka koefisien korelasi 0,264 dan karena angka pada kolom sig. adalah 0,155>0,05 maha ho diterima dan ha ditolak artinya tidak ada hubungan peran pola asuh orang tua terhadap kematangan sosial anak usia prasekolah.

Kesimpulan: Tidak ada hubungan peran pola asuh orang tua terhadap kematangan sosial anak usia prasekolah. Rekomendasi yang dapat diberikan adalah peneliti berikutnya diharapkan dapat melakukan penelitian lanjutan dengan menambah variabel yang lain, sehingga akan menambah referensi mengenai peran pola asuh orang tua kaitannya dengan aspek perkembangan yang lain pada anak.
\end{abstract}

Kata kunci : pola asuh, kematangan sosial, pra sekolah

\begin{abstract}
Background: Parenting is very important role in the development of child psychology because it can shape the child's personality in the future. Social maturity is a development of individual skills and habits that characterize the group. Some children around us may experience barriers to social maturity such as children who have not been able to complete developmental tasks at their age, such as a 3-years-old child who has not been able to urinate in the toilet.

Purpose: This study aims to determine the relationship of the role of parenting on social maturity of preschool children.

Methods: This research method is an observational analytic using cross-sectional study design. The sampling technique uses total sampling in which the number of research
\end{abstract}


samples is 30 respondents. The parenting instrument uses the Parenteral Authority Questionnary (PAQ) and social maturity using the Vineland Social Maturity Scale (VSMS). The research analysis uses the Kendall Tau test.

Results: This study found a correlation coefficient of 0.264 and because of the numbers in the sig column. is $0.155>0.05$ so that its meaning there is no relationship between the role of parenting on the social maturity of preschool children.

Conclusion: There is no relationship between the role of parenting on the social maturity of preschool children. The recommendation that can be given is that the next researcher is expected to be able to carry out further research by adding other variables, so that it will add a reference regarding the role of parenting parents in relation to other aspects of development in children.

Keywords: parenting, social maturity, preschool

\section{Pendahuluan}

Kualitas anak masa kini merupakan penentu kualitas sumber daya manusia di masa yang akan datang. Oleh karena itu anak harus dipersiapkan agar dapat tumbuh dan berkembang secara optimal. Tumbuh dan berkembang secara optimal dapat tercapai apabila ada interaksi yang saling berkaitan antara faktor genetik dan lingkungan bio-psiko-sosial dan perilaku. Interaksi anak dan orang tua, terutama peranan orang tua yang sangat bermanfaat bagi proses perkembangan anak secara keseluruhan (Soetjiningsih, 2012). Terdapat beberapa anak di sekitar kita yang mengalami hambatan kematangan sosial, yaitu anak yang belum mampu menyelesaikan tugas perkembangan pada usianya, seperti anak berusia 3 tahun yang belum mampu buang air kecil di toilet. Individu yang belum mampu menyelesaikan tugas perkembangannya akan mengalami kegagalan pada tugas perkembangan selanjutnya (Havighurst dalam Berns, 2010).

Menurut Yusuf (2011) prevalensi permasalahan pada anak berkisar dari $3,5 \%$ untuk masalah perhatian dan hiperaktivitas, $10,4 \%$ untuk masalah kecemasan, dan 21,9\% untuk ganggguan pada tingkah laku. Sedangkan berdasarkan data rekam medik yang ada di Unit Rawat Jalan Poli Tumbuh Kembang Anak RSU Dr Soetomo Surabaya pada tahun 2011 ditemukan adanya gangguan perkembangan sebesar 1887 anak yang meliputi: gangguan motorik 
521 anak (27,61\%), gangguan personal sosial 302 anak (16\%), gangguan bicara $622(32,96 \%)$, gangguan perkembangan yang lain 442 anak $(23,42 \%)$.

Orang tua seringkali keliru dalam memperlakukan anak karena ketidaktahuan mereka akan cara membimbing dan mengasuh yang benar. Pakar emotional intellegent dari Radani Edutainment, Hanny Muchtar Darta, mengatakan bahwa pengaruh pola asuh orang tua memiliki dampak besar pada kehidupan anak di kemudian hari. Biasanya terjadi ketika anak dibawah lima atau enam tahun dan dibawah 11 tahun. Semua orang tua mempunyai tujuan yang sangat baik untuk anaknya, tetapi kebanyakan orang tua tidak memahami dampak jangka panjang akibat dari pola asuh yang tidak tepat. Macam-macam pola asuh terdiri dari pola asuh otoriter, permisif, dan demokratis. Pola asuh yang tepat dan efektif sangat penting peranannya dalam pengembangan psikologi anak karena bisa membentuk kepribadian anak di masa depan. Kehidupan awal anak dimulai dari orang tua dan rumahnya. Karena itu, orang tualah yang bertanggung jawab terhadap masa depan anak karena semua tergantung orang tua pada saat pertama kali menetapkan tujuan dan harapan terhadap anaknya di masa depan. Jika sampai terjadi kesalahan dalam pola asuh, efeknya tidak hanya akan dirasakan oleh anak, tetapi orang tua juga pasti akan ikut merasakannya. Meski begitu semua itu tidak bisa digeneralisasi pasti akan terjadi pada setiap orang tua yang salah menerapkan pola asuh pada anaknya, karena banyak juga yang terjadi justru sebaliknya. Semua kembali pada karakter dan lingkungan anak tersebut tumbuh dan berkembang.

Studi pendahuluan di TK Desa Toriyo Sukoharjo terdapat lebih kurang 30 murid yang terdiri dari kelompok A usia 4 - 5 tahun sebanyak 20 anak dan kelompok B sebanyak 10 anak. Berdasarkan hal tersebut, maka peneliti tertarik melakukan penelitian tentang hubungan pola asuh orang tua dengan masalah kematangan sosial, khususnya pada anak prasekolah usia 4 - 6 tahun.

\section{Tujuan}

Tujuan dari penelitian ini adalah untuk mengetahui hubungan peran pola asuh orang tua terhadap kematangan sosial anak usia prasekolah. 


\section{Metode}

Penelitian ini telah dilakukan di TK Desa Toriyo, Sukoharjo pada bulan Maret - April 2018 menggunakan metode observasional analitik dengan rancangan cross-sectional. Teknik sampel yang digunakan yaitu total sampling dari jumlah populasi anak usia $4-6$ tahun di TK Desa Toriyo yaitu sejumlah 30 anak. Responden penelitian adalah orang tua (mengisi lembar kuesioner pola asuh) dan anak (diobservasi kematangan soaialnya). Instrumen yang digunakan tentang Pola asuh orang tua adalah kuesioner Parenteral Authority Questionnary (PAQ) (Buri, 1991) yang dikutip Sukesi (2013) sejumlah 30 item dan telah dimodifikasi oleh peneliti sebelumnya, sedangkan untuk menilai kematangan sosial menggunakan Vineland Social Maturity Scale (VSMS). Responden terlebih dahulu diberikan informed consent dan penjelasan terkait penelitian. Analisis data menggunakan uji Kendall Tau.

\section{Hasil}

Penelitian ini diikuti oleh 30 responden orang tua anak di TK Desa Toriyo, Sukoharjo. Berikut ini adalah hasil penelitian karakteristik responden berdasarkan jenis kelamin anak, usia anak, urutan anak, pengasuh di rumah, usia orang tua, pendidikan orang tua, pekerjaan orang tua.

Tabel 1. Karakteristik responden menurut jenis kelamin anak $(n=30)$

\begin{tabular}{ccc}
\hline Jenis Kelamin Anak & Frekuensi & Prosentase \\
\hline Laki-laki & 11 & $36,7 \%$ \\
Perempuan & 19 & $63,3 \%$ \\
Jumlah & 30 & $100 \%$ \\
\hline
\end{tabular}

Tabel 1. Menunjukkan bahwa data responden anak yang berjenis kelamin perempuan 19 anak $(63,3 \%)$ lebih banyak dibandingkan yang berjenis kelamin laki-laki 11 anak $(36,7 \%)$.

Tabel 2. Karakteristik responden menurut usia anak $(\mathrm{n}=30)$

\begin{tabular}{ccc}
\hline Usia Anak & Frekuensi & Prosentase \\
\hline 4 tahun & 4 & $13,3 \%$ \\
5 tahun & 5 & $16,7 \%$ \\
6 tahun & 11 & $36,7 \%$ \\
7 tahun & 10 & $33,3 \%$ \\
Jumlah & 30 & $100 \%$ \\
\hline
\end{tabular}


Tabel 2. Menunjukkan data responden anak paling banyak berusia 6 tahun sebanyak 11 anak (36,7\%) sedangkan paling sedikit berusia 4 tahun sebanyak 4 anak $(13,3 \%)$.

Tabel 3. Karakteristik responden menurut urutan anak $(n=30)$

\begin{tabular}{ccc}
\hline Urutan Anak & Frekuensi & Prosentase \\
\hline Pertama & 15 & $50 \%$ \\
Kedua & 11 & $36,7 \%$ \\
Ketiga & 4 & $13,3 \%$ \\
\hline Jumlah & 30 & $100 \%$ \\
\hline
\end{tabular}

Tabel 3. Menunjukkan bahwa data responden anak pertama sebanyak 15 anak (50\%) dan paling sedikit merupakan anak ketiga sebanyak 4 anak $(13,3 \%)$.

Tabel 4. Karakteristik responden menurut pengasuh anak di rumah $(n=30)$

\begin{tabular}{ccc}
\hline Pengasuh di Rumah & Frekuensi & Prosentase \\
\hline Orang tua & 25 & $83,3 \%$ \\
Kakek/nenek & 3 & $10 \%$ \\
Saudara bapak/ibu & 2 & $6,7 \%$ \\
\hline Jumlah & 30 & $100 \%$
\end{tabular}

Tabel 4. Menunjukkan bahwa anak mayoritas diasuh orang tua sebanyak 25 anak $(83,3 \%)$ dan paling sedikit diasuh saudara bapak/ibu sebanyak 2 anak $(6,7 \%)$.

Tabel 5. Karakteristik responden menurut usia orang tua $(n=30)$

\begin{tabular}{ccc}
\hline Usia Orang tua & Frekuensi & Prosentase \\
\hline$<20$ tahun & - & - \\
$20-30$ tahun & 10 & $33,3 \%$ \\
$30-40$ tahun & 17 & $56,7 \%$ \\
$>40$ tahun & 3 & $10 \%$ \\
Jumlah & 30 & $100 \%$ \\
\hline
\end{tabular}

Tabel 5. Menunjukkan bahwa mayoritas orang tua berusia 30-40 tahun sebanyak 17 orang $(56,7 \%)$ dan paling sedikit berusia $>40$ tahun sebanyak 3 orang $(10 \%)$.

Tabel 6. Karakteristik responden menurut pendidikan orang tua $(\mathrm{n}=30)$

\begin{tabular}{ccc}
\hline Pendidikan Orang tua & Frekuensi & Prosentase \\
\hline Dasar & 3 & $10 \%$ \\
Menengah & 19 & $63,3 \%$ \\
Tinggi & 8 & $26,7 \%$ \\
Jumlah & 30 & $100 \%$
\end{tabular}

Tabel 6. Menunjukkan bahwa mayoritas orang tua berpendidikan menengah sebanyak 19 orang $(63,3 \%)$ dan paling sedikit berpendidikan tinggi sebanyak 8 orang $(26,7 \%)$. 
Intan Husada : Jurnal Ilmiah Keperawatan, Vol. 8 No. 2, Juli 2020

Tabel 7. Karakteristik responden menurut pekerjaan orang tua $(n=30)$

\begin{tabular}{ccc}
\hline Pekerjaan Orang tua & Frekuensi & Prosentase \\
\hline PNS & - & - \\
Swasta & 16 & $53,3 \%$ \\
Tidak bekerja & 14 & $46,7 \%$ \\
Jumlah & 30 & $100 \%$ \\
\hline
\end{tabular}

Tabel 7. Menunjukkan bahwa mayoritas orang tua bekerja sebagai swasta sebanyak 16 orang $(53,3 \%)$ dan tidak bekerja sebanyak 14 orang $(46,7 \%)$.

Sedangkan hasil analisis bivariat menggunakan uji Kendal Tau adalah sebagai berikut:

Tabel 8. Uji Kendal Tau

\begin{tabular}{|c|c|c|c|c|c|c|c|c|c|}
\hline \multirow{3}{*}{\multicolumn{2}{|c|}{ Pola Asuh }} & \multicolumn{6}{|c|}{ Kematangan Sosial } & \multirow{3}{*}{ Tau } & \multirow{3}{*}{ Sig. } \\
\hline & & \multicolumn{2}{|c|}{$\begin{array}{c}\text { Di atas rata- } \\
\text { rata }\end{array}$} & \multicolumn{2}{|c|}{ Sesuai usia } & \multicolumn{2}{|c|}{$\begin{array}{c}\text { Kurang sesuai } \\
\text { usia }\end{array}$} & & \\
\hline & & $\mathrm{f}$ & $\%$ & $\mathrm{f}$ & $\%$ & $\mathrm{f}$ & $\%$ & & \\
\hline Permisif & & - & - & - & - & - & - & \multirow{6}{*}{0,264} & \multirow{6}{*}{0,155} \\
\hline Otoriter & & - & - & - & - & - & - & & \\
\hline Demokratis & & - & - & 19 & $63,3 \%$ & 3 & $10 \%$ & & \\
\hline $\begin{array}{l}\text { Demokratis } \\
\text { permisif }\end{array}$ & + & - & - & - & - & - & - & & \\
\hline Demokratis + otorite & & - & - & 5 & $16,7 \%$ & 3 & $10 \%$ & & \\
\hline Jumlah & & - & - & 24 & $80 \%$ & 6 & $20 \%$ & & \\
\hline
\end{tabular}

Tabel 8. Menunjukkan hasil pola asuh demokratis dengan tingkat kematangan sosial anak sesuai usia sebanyak 19 anak $(63,3 \%)$ dan pola asuh demokratis dengan tingkat kematangan sosial anak yang kurang sesuai usia sebanyak 3 anak (10\%). Angka koefisien korelasi 0,264 dan karena angka pada kolom sig. adalah $0,155>0,05$ maha ho diterima dan ha ditolak artinya tidak ada hubungan peran pola asuh orang tua terhadap kematangan sosial anak usia prasekolah.

\section{Pembahasan}

Pada penelitian ini, klasifikasi jenis kelamin responden yang paling banyak adalah perempuan 19 anak (63,3\%). Jenis kelamin membedakan pola interaksi sosial anak antara anak perempuan dan anak laki-laki yang mempengaruhi pula pada kematangan sosial anak. Dua anak yang usianya sama tetapi berjenis kelamin berbeda, maka kematangan sosialnya pada aspek-aspek tertentu tentu berbeda.

Sesuai klasifikasi usia, anak paling banyak berusia 6 tahun sebanyak 11 anak $(36,7 \%)$ sedangkan paling sedikit berusia 4 tahun sebanyak 4 anak 
$(13,3 \%)$. Semakin bertambahnya usia anak, ia akan semakin trampil, semakin besar variasi dan keterampilannya, semakin baik pula kualitasnya (Hurlock, 1998). Pada penelitian ini, sebagian siswa yang kakaknya bersekolah di TK Desa Toriyo apabila memiliki adik yang usianya tidak jauh disekolahkan di tempat yang sama.

Berdasarkan hasil penelitian diperoleh data responden anak pertama sebanyak 15 anak (50\%) dan paling sedikit merupakan anak ketiga sebanyak 4 anak (13,3\%). Menurut Stein (1970) yang dikutip Herwani (2013) bahwa anak yang lahir kedua selalu merasa tidak pernah mendapat perhatian penuh dari orang tuanya, selalu memiliki saudara (kakak) yang lebih diperhatikan daripada dirinya, seperti di dalam lomba, anak kedua selalu mencoba untuk mengejar atau menyusul anak pertama. Jika anak pertama adalah "baik" atau berhasil, maka anak kedua mungkin menjadi buruk atau merasa tidak pasti tentang dirinya dan kemampuannya bahkan mungkin menjadi pemberontak. Dalam penelitian ini anak pertama lebih banyak dibandingkan anak kedua dan anak ketiga.

Hasil penelitian berdasarkan pengasuhan, anak mayoritas diasuh orang tua sebanyak 25 anak $(83,3 \%)$ dan paling sedikit diasuh saudara bapak/ibu sebanyak 2 anak (6,7\%). Anak yang diasuh oleh orang tuanya sendiri tanpa orang lain lebih banyak dibanding anak yang diasuh oleh orang tuanya beserta nenek, kakek dan pembantu rumah tangga. Menurut penelitian Sukesi (2014) menunjukkan hasil uji Eksak dari Fisher diperolep $\mathrm{p}=0,426(\mathrm{p}>0,05)$ menunjukan bahwa tidak ada hubungan antara pengasuh anak di rumah dengan mental emosional anak.

Data responden sesuai usia orang tua, mayoritas orang tua berusia 30-40 tahun sebanyak 17 orang $(56,7 \%)$ dan paling sedikit berusia $>40$ tahun sebanyak 3 orang $(10 \%)$. Orang tua dalam penelitian ini sangat sedikit yang berada pada fase dewasa muda maupun lebih dari 40 tahun sehingga orang tua cukup mampu untuk menempatkan diri dalam situasi yang berbeda, khususnya dalam hal pengasuhan anak.

Mayoritas orang tua berpendidikan menengah sebanyak 19 orang $(63,3 \%)$ dan paling sedikit berpendidikan tinggi sebanyak 8 orang $(26,7 \%)$. Hasil penelitian Sukesi (2013), responden ibu dengan latar belakang pendidikan 
menengah dan tinggi sebagian besar menerapkan pola asuh demokratis terhadap anaknya. Demikian juga dengan ayah yang berlatar belakang pendidikan menengah dan tinggi hampir seluruhnya menerapkan pola asuh demokratis. Hasil uji Eksak dari Fisher didapatkan tidak ada hubungan antara pendidikan ayah dengan pola asuh ayah terhadap anak.

Responden mayoritas orang tua bekerja sebagai swasta sebanyak 16 orang $(53,3 \%)$ dan sisanya tidak bekerja sebanyak 14 orang $(46,7 \%)$. Sebagian besar orang tua dalam penelitian ini adalah bekerja. Ibu yang bekerja diluar rumah pada zaman yang sudah modern saat ini merupakan suatu hal yang biasa dan merupakan tuntutan masyarakat yang sudah maju, karena dengan bekerja mengurangi kejenuhan di dalam mengurus rumah tangga dan dapat menambah penghasilan keluarga, menambah wawasan serta pengetahuan dalam pergaulan di dalam masyarakat. Menurut Gunarsa (2010) orang tua yang terlalu lelah karena pekerjaan baik di luar atau di dalam rumahnya menempatkan orang tua pada suatu kedudukan dimana secara tidak sadar ia menjadi tokoh yang kurang sabar dalam menghadapi anak-anaknya, bila interaksi antara orang tua dan anak tidak maksimal menyebabkan kurangnya komunikasi, anak kurang mendapatkan kasih sayang dari orang ruanya karena orang tua terlalu sibuk dengan pekerjaaanya. Jadi orang tua yang bekerja di luar rumah sebaiknya bisa membagi waktu untuk pekerjaaan dan untuk rumah tangganya dan orang tua tidak hanya mengandalkan anak di asuh oleh pengasuh saja.

Data khusus penelitian diperoleh data mayoritas orang tua menerapkan pola asuh demokratis dengan tingkat kematangan sosial sesuai usia sebanyak 19 anak (63,3\%). Angka koefisien korelasi 0,264 dan sig. 0,155>0,05 maha ho diterima dan ha ditolak yang artinya tidak ada hubungan peran pola asuh orang tua terhadap kematangan sosial anak usia prasekolah. Menurut Baumrind (1967) dalam Yusuf (2011) memaparkan bahwa pola asuh demokratis adalah pola asuh yang memprioritaskan kepentingan anak, akan tetapi tidak ragu-ragu untuk mengendalikan mereka, pendekatannya bersifat hangat, selalu mengarahkan aktifitas anak secara rasional, senantiasa mendorong anak untuk menyatakan pendapat atau bertukar pikiran dengan anak mengenai kebijakannya dan menerima rasa keberatan anak jika anak merasa sulit untuk menyesuaikan diri 
serta memberikan penjelasan tentang dampak perbuatan yang baik maupun yang buruk. Anak mendapatkan kebebasan untuk memilih dan melakukan suatu tindakan secara bertanggung jawab dibawah pengawasan orang tua dan dapat dipertanggung jawabkan secara moral. Hasil penelitian ini sesuai dengan pendapat Baumrind (1967) dalam Yusuf (2011) bahwa pola asuh demokratis memang merupakan pola asuh yang terbaik dalam mendukung perkembangan anak.

Model Kathryn E.Bannard menjadi dasar penjelasan dengan tiga konsep utama, yaitu anak, orang tua, dan lingkungan. Anak menunjukkan kemampuan untuk beradaptasi kepada pengasuh dan lingkungannya. Orang tua menunjukkan identitas sebagai orang tua dari anaknya atau pengasuh utama dan memiliki karakteristik yang penting. Karakteristik tersebut meliputi kemampuan psikososial, kepedulian terhadap anak dan kesehatannya, pengalaman yang dimiliki, harapan terhadap anaknya, dan yang terpenting adalah gaya orang tua dan kemampuan beradaptasi. Lingkungan merupakan aspek lingkungan fisik keluarga, keterlibatan ayah, dan tingkat hubungan orang tua dengan anak yang saling menghormati. Suharsono (2009) menjelaskan bahwa apabila orang tua menerapkan pola asuh yang tepat maka akan mempengaruhi kemampuan sosialisasi anak, karena anak hidup dalam keluarga yang selalu mendukungnya dalam cinta kasih, sehingga anak bisa tumbuh dan berkembang secara optimal. Orang tua harus mengetahui tumbuh kembang anak yang normal sesuai usia anak. Kemudian pola asuh orang tua terhadap anak usia prasekolah tidak hanya menggunakan satu model pola asuh saja, tetapi dapat dikombinasikan dari keempat model pola asuh sesuai kondisi dan situasi perkembangan anak tersebut. Sehingga dapat dikatakan bahwa penggunaan keempat model pengasuhan orang tua akan menghasilkan pengasuhan yang baik terhadap perkembangan perilaku sosial anak khususnya pada anak usia prasekolah.

\section{Kesimpulan}

Kesimpulan dari penelitian ini adalah anak paling banyak berjenis kelamin perempuan 19 anak (63,3\%), anak paling banyak berusia 6 tahun sebanyak 11 anak (36,7\%), merupakan anak pertama sebanyak 15 anak (50\%), 
mayoritas diasuh orang tua sebanyak 25 anak (83,3\%), mayoritas orang tua berusia 30-40 tahun sebanyak 17 orang $(56,7 \%)$, mayoritas orang tua berpendidikan menengah sebanyak 19 orang $(63,3 \%)$, orang tua mayoritas bekerja sebagai swasta sebanyak 16 orang $(53,3 \%)$, orang tua yang menerapkan pola asuh demokratis sebanyak 22 orang $(73,3 \%)$ dan kematangan sosial yang sesuai usia sebanyak 24 anak (80\%). Angka koefisien korelasi 0,264 dan sig. 0,155 > 0,05 yang artinya tidak ada hubungan peran pola asuh orang tua terhadap kematangan sosial anak usia prasekolah.

Saran yang dapat disampaikan adalah orang tua diharapkan mengetahui tumbuh kembang anak yang normal sesuai usia anak dan menerapkan keempat model pola asuh sesuai dengan kondisi dan situasi khususnya pada anak usia prasekolah. Untuk peneliti berikutnya diharapkan dapat melakukan penelitian lanjutan dengan menambah variabel yang lain, sehingga akan menambah referensi mengenai peran pola asuh orang tua kaitannya dengan aspek perkembangan yang lain pada anak.

\section{Daftar pustaka}

Berns R . M. (2010). Child, Family, Schoola, and Community, 8 th Edition, Socialization and Support. California: Wadsworth.

Braumrind, D. (1991). The influenceofparenting style on adolescent competence and subtance use, journal of early adolescent, [Internet], avelable from: http//www.osmond.co/onset/family.

Coleman JC, Butcher JN, Carson RC. (1980), Abnormal Psychology and Modern Life, 6th edition. New York USA: Scott, Foreman and Company.

Cooper Carol, Claire Halsey, Su Laurent, Karen Sullivan (Alih Bahasa Listiani Nadia). (2009). Ensiklopedia Perkembangan Anak. Jakarta: Penerbit Erlangga.

Dharma, Kelana Kusuma. (2011). Metodologi penelitian keperawatan. Jakarta: Trans Info media.

Doll, E.A. (1965). Vineland Social Maturity Scale. Manual of Directors Minessota: American Duidance Service, Inc.

Fuadda, Fiki. (2013). Hubungan Urutan kelahiran Anak dengan Perkembangan Personal Soial Anak Usia Pra Sekolah (3-5 Tahun) di TK Bangunsari Pacitan. Surakarta: UMS. 
Gunarsa, S.D. (2000). Psikologi Perkembangan Anak dan Remaja. Cetakan ke12. Jakarta: Gunung Mulia.

Hasanah, Uswatun. (2016). Sikap Overproteksi Orang Tua dan kematangan Sosial Anak. Journal An-Nafs: Kajian dan Penelitian Psikologi. Vol 1. No.1.

Hurlock, EB. (1991). Perkembangan Anak, Edisi 6, Jilid 1. Jakarta: Penerbit Erlangga.

Hurlock, EB. (1993). Psikologi Perkembangan: Suatu Pendekatan Sepanjang Rentang Kehidupan. Jakarta: Erlangga Press.

(1998). Psikologi Perkembangan: Suatu Pendekatan Sepanjang Rentang Kehidupan. Jakarta: Erlangga Press.

Soetjiningsih, Hc. (2012). Perkembangan Anak Sejak Pertumbuhan Sampai Dengan Kanak-kanak Akhir. Jakarta: Prenada Media Group.

Sukesi. (2013). Hubungan Antara Pola Asuh dengan Mental Emosional Anak Usia Prasekolah. Tesis. Universitas Airlangga.

Wina, Levia, Yudiernawati, Atti, Maemunah, Neni. (2016). Hubungan Pola Asuh Orang Tua Dengan Perkembangan Sosial Anak Usia Prasekolah (4-6 Tahun) Di TK Muslimat Ar-Rohmah Gading Kembar Kecamatan Jabung Kabupaten Malang. Nursing News Volume 1, Nomor 1.

Yusuf, S. (2011). Psikologi Perkembangan Anak dan Remaja. Bandung: PT. Remaja Rosdakarya. 